\title{
A Computational Determination of the Lowest Energy Electronic and Geometric States of First Row Transition Metal Dioxygen Dications
}

\author{
Jillian Lennartz, ${ }^{1}$ Eric Dumas, ${ }^{2}$ Lennie Ramirez, ${ }^{2}$ and John Morrison Galbraith ${ }^{2}$ \\ ${ }^{1}$ Environmental Resource Management, 1 Beacon Street, 5th Floor, Boston, MA 02108, USA \\ ${ }^{2}$ Department of Chemistry, Biochemistry, and Physics, Marist College, 3399 North Road, Poughkeepsie, NY 12601, USA \\ Correspondence should be addressed to John Morrison Galbraith; john.galbraith@marist.edu
}

Received 28 March 2013; Accepted 13 August 2013

Academic Editors: G. Borosky, P. Derosa, G. Pacchioni, A. Stavrakoudis, A. Tilocca, and B. M. Wong

Copyright (c) 2013 Jillian Lennartz et al. This is an open access article distributed under the Creative Commons Attribution License, which permits unrestricted use, distribution, and reproduction in any medium, provided the original work is properly cited.

\begin{abstract}
The lowest energy geometric structures and electronic spin states of first row transition metal (TM) dioxygen dication molecules $\left(\left[\mathrm{TM}-\mathrm{O}_{2}\right]^{2+} ; \mathrm{TM}=\mathrm{Sc}, \mathrm{Ti}, \mathrm{V}, \mathrm{Cr}, \mathrm{Mn}, \mathrm{Fe}, \mathrm{Co}, \mathrm{Ni}, \mathrm{Cu}\right.$, and $\mathrm{Zn}$ ) have been determined at the B3LYP/LANL2DZ level of theory (along with an extra $d$-type polarization function added to the $\mathrm{O}$ atoms). In order to further verify the spin states, $\operatorname{CASSCF}(6+n, 9)$ energy points were determined ( $n=$ number of TM $d$ electrons). It has been found that with the exception of $\left[\mathrm{Sc}-\mathrm{O}_{2}\right]^{2+},\left[\mathrm{V}-\mathrm{O}_{2}\right]^{2+}$, $\left[\mathrm{Co}-\mathrm{O}_{2}\right]^{2+}$, and $\left[\mathrm{Ni}-\mathrm{O}_{2}\right]^{2+}$, all $\left[\mathrm{TM}-\mathrm{O}_{2}\right]^{2+}$ molecules take on a high-spin state. $\left[\mathrm{Sc}-\mathrm{O}_{2}\right]^{2+}$ adopts a trigonal structure, while $[\mathrm{Ti}-$ $\left.\mathrm{O}_{2}\right]^{2+}-\left[\mathrm{Mn}-\mathrm{O}_{2}\right]^{2+}$ are essentially linear and $\left[\mathrm{Fe}-\mathrm{O}_{2}\right]^{2+}-\left[\mathrm{Zn}-\mathrm{O}_{2}\right]^{2+}$ are bent. It is further noted that the O-O bond decreases from $130.0 \mathrm{pm}$ to $118.1 \mathrm{pm}$ as the TM changes from Sc to $\mathrm{Zn}$. However, the TM-O $\mathrm{O}_{2}$ bond lengths fluctuate between values of $182.2 \mathrm{pm}$ for $\left[\mathrm{Ni}-\mathrm{O}_{2}\right]^{2+}$ and $232.2 \mathrm{pm}$ for $\left[\mathrm{Zn}-\mathrm{O}_{2}\right]^{2+}$.
\end{abstract}

\section{Introduction}

Transition metals (TMs) bound to an $\mathrm{O}_{2}$ molecule are the chemically active site in many industrial $[1-5]$ and biological $[1,2,6-10]$ molecules. Considering the $\mathrm{TM}-\mathrm{O}_{2}$ bond to lie along the $z$-axis of a Cartesian coordinate system, in TM-O complexes, bonds can form by the interactions of TM $3 d_{z^{2}}$, $3 d_{y z}$, and $3 d_{x z}$ atomic orbitals with suitable orbitals on the $\mathrm{O}_{2}$ ligand in order to make $\sigma\left(3 d_{z^{2}}\right)$ or $\pi\left(3 d_{y z}\right.$ and $\left.3 d_{x z}\right)$ bonds (Scheme 1). While there have been numerous studies of neutral TM-O $\mathrm{O}_{2}[11,12]$ complexes, in many $\mathrm{TM}-\mathrm{O}_{2}$ containing molecules of biological and industrial importance, the TM is bound to a porphyrin ring in the $2^{-}$oxidation state. Therefore, $\left[\mathrm{TM}-\mathrm{O}_{2}\right]^{2+}$ molecules are the simplest approximations to this important class of $\mathrm{TM}-\mathrm{O}_{2}$ containing molecules.

Probably the most studied TM-O $\mathrm{O}_{2}$ bond is the $\mathrm{Fe}-\mathrm{O}_{2}$ bond due to its role in heme-containing proteins [13-16]. This bond has been described as low-spin $\mathrm{Fe}(\mathrm{II})$ accepting an electron pair from excited singlet-state $\mathrm{O}_{2}$ forming the $\sigma$ bond, while donating an electron pair to oxygen to form a $\pi$ bond. An alternative view involves Fe(III) interacting with
$\mathrm{O}^{2-}$. In a third possibility, triplet $\mathrm{Fe}(\mathrm{II})$ couples with triplet $\mathrm{O}_{2}$ to form a closed shell singlet. Computational results vary depending on the extent of electron correlation and basis set size. It is clear, however, that the overall bonding scheme involves some degree of both $\mathrm{O}_{2} \rightarrow \mathrm{Fe}$ and $\mathrm{Fe} \rightarrow \mathrm{O}_{2} \sigma$ and $\pi$ electron transfer.

Further complicating matters, the number of near degenerate TM $d$-orbitals leads to the possibility of many low lying spin states. In addition, there are a number of different ways that the $\mathrm{O}_{2}$ unit can be arranged relative to the TM. Herein, we seek to determine the lowest energy electronic and geometric states of $\left[\mathrm{TM}-\mathrm{O}_{2}\right]^{2+}$ molecules $(\mathrm{TM}=\mathrm{Sc}, \mathrm{Ti}, \mathrm{V}, \mathrm{Cr}$, $\mathrm{Mn}, \mathrm{Fe}, \mathrm{Co}, \mathrm{Ni}, \mathrm{Cu}$, and $\mathrm{Zn}$ ) as a precursor to a more in-depth study of the $\mathrm{TM}-\mathrm{O}_{2}$ bond.

\section{Theoretical Methods}

In order to locate the lowest energy geometrical configuration, B3LYP [17-19] geometry optimizations were performed using the LANL2DZ [20-22] effective core potential basis 
TABLE 1: Lowest energy spin states and geometric parameters of $\left[\mathrm{TM}-\mathrm{O}_{2}\right]^{2+}$ molecules. Bond lengths in pm and bond angles in degree.

\begin{tabular}{lcccc}
\hline & Spin state & $\mathrm{O}-\mathrm{O}$ & TM-O & \\
\hline$\left[\mathrm{ScO}_{2}\right]^{2+}$ & Doublet & 130.0 & 195.4 & 70.6 \\
{$\left[\mathrm{TiO}_{2}\right]^{2+}$} & Triplet & 124.2 & 176.5 & 180.0 \\
{$\left[\mathrm{VO}_{2}\right]^{2+}$} & Doublet & 121.0 & 197.1 & 180.0 \\
{$\left[\mathrm{CrO}_{2}\right]^{2+}$} & Triplet & 120.9 & 193.4 & 180.0 \\
{$\left[\mathrm{MnO}_{2}\right]^{2+}$} & Quartet & 120.7 & 200.6 & 175.4 \\
{$\left[\mathrm{FeO}_{2}\right]^{2+}$} & Triplet & 120.2 & 196.3 & 161.9 \\
{$\left[\mathrm{CoO}_{2}\right]^{2+}$} & Doublet & 120.0 & 198.3 & 144.4 \\
{$\left[\mathrm{NiO}_{2}\right]^{2+}$} & Singlet & 116.3 & 182.2 & 127.7 \\
{$\left[\mathrm{CuO}_{2}\right]^{2+}$} & Quartet & 124.4 & 196.7 & 137.5 \\
{$\left[\mathrm{ZnO}_{2}\right]^{2+}$} & Triplet & 118.1 & 232.2 & 126.0 \\
\hline
\end{tabular}

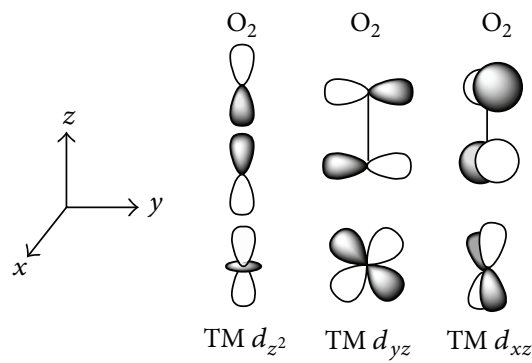

SCHEMe 1
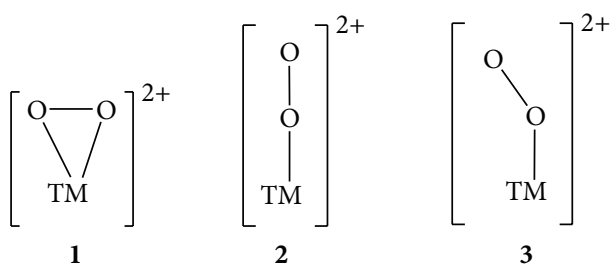

SCHEME 2

set with an additional $d$-type polarization function $(\zeta=$ 0.9610) on the $\mathrm{O}$ atoms [23]. Optimizations began with trigonal, linear, and bent starting structures as shown in Scheme 2. Optimizations at all three starting geometries were performed for singlet, triplet, and quintet spin states for [TM$\left.\mathrm{O}_{2}\right]^{2+}$ molecules with an even number of electrons $(\mathrm{TM}=\mathrm{Ti}$, $\mathrm{Cr}, \mathrm{Fe}, \mathrm{Ni}$, and $\mathrm{Zn}$ ) and doublet, quartet, and sextet spin states for molecules with an odd number of electrons $(\mathrm{TM}=\mathrm{Sc}, \mathrm{V}$, $\mathrm{Mn}, \mathrm{Co}$, and $\mathrm{Cu}$ ).

In order to further verify the spin state of each molecule, CASSCF [24-29] energy point calculations were performed for the various different spin states at the lowest energy B3LYP conformation. The CASSCF active space consisted of nine orbitals: the 5 TM $d$-type orbitals along with the $\pi$ and $\pi^{*}$ $\mathrm{O}_{2}$ combinations (Scheme 3). Six electrons were placed into this active space from the $\mathrm{O}_{2} \pi$ and $\pi^{*}$ orbitals, along with the TM $d$ electrons (i.e., 1 for Sc, 2 for Ti, etc.).

All calculations were carried out with the Gaussian 03 [30] suite of programs.

\section{Results and Discussion}

The geometric parameters and spin states of the lowest energy structures of all $\left[\mathrm{TM}-\mathrm{O}_{2}\right]^{2+}$ molecules studied herein are reported in Table 1.

$\left[\mathrm{Sc}-\mathrm{O}_{2}\right]^{2+}$ adopts a trigonal structure as in $\mathbf{1}$ of Scheme 2. This can be thought of as the $\mathrm{Sc}^{2+}$ atom bonding to the $\pi$ system of $\mathrm{O}_{2}$. The single $d$ electron of $\mathrm{Sc}^{2+}$ spin pairs with the single electron in the $\pi^{*}{ }_{z} \mathrm{MO}$ of $\mathrm{O}_{2}$ as depicted in Scheme 3 (MO 2 $\sigma, 1$ ), while one electron remains in the $\pi^{*}{ }_{x} \mathrm{MO}$ of $\mathrm{O}_{2}$ $(\mathrm{MO} 2 \pi, 1)$ resulting in a doublet ground state.

$\left[\mathrm{Ti}-\mathrm{O}_{2}\right]^{2+},\left[\mathrm{V}-\mathrm{O}_{2}\right]^{2+},\left[\mathrm{Cr}-\mathrm{O}_{2}\right]^{2+}$, and $\left[\mathrm{Mn}-\mathrm{O}_{2}\right]^{2+}$ are essentially linear with the $\mathrm{O}_{2}$ binding end-on to the $\mathrm{TM}^{2+}$. The slight bending in $\left[\mathrm{Ti}-\mathrm{O}_{2}\right]^{2+}$ breaks the degeneracy of the $2 \pi$ and $1 \delta$ MOs. The observed triplet is the result of the subtle balance between orbital energies and favorable electron exchange. Doublet $\left[\mathrm{V}-\mathrm{O}_{2}\right]^{2+}$ has one electron in the $1 \delta \mathrm{MO}$, and triplet $\left[\mathrm{CrO}_{2}\right]^{2+}$ has one electron in each of the degenerate $1 \delta$ MOs (Scheme 3, 2). In order for the high spin quartet to be the lowest energy state of $\left[\mathrm{Mn}-\mathrm{O}_{2}\right]^{2+}$, one electron must remain in each of the $1 \delta \mathrm{MOs}$, while another single electron occupies the $1 \sigma$ MO (Scheme 3, 2). This situation is only possible if the $1 \sigma$ and $1 \delta$ MOs are close enough in energy that exchange stabilization outweighs the destabilization introduced by placing an electron in the higher energy $1 \sigma \mathrm{MO}$.

Upon examination of Scheme 3, it would appear that [Fe$\left.\mathrm{O}_{2}\right]^{2+}$ should continue the trend of linearity by completely filling the $1 \delta \mathrm{MO}$ thus forming a stable singlet. Indeed, a stable linear singlet was found; however, it was $18.2 \mathrm{~kJ} / \mathrm{mol}$ above the bent triplet ground state. Upon bending, the linear $1 \delta \mathrm{MO}$ (Scheme 3,2) splits into the bent $3 \sigma$ and $1 \delta \mathrm{MOs}$ (Scheme 3, 3). This results in a stabilization of the $3 \sigma \mathrm{MO}$ due to increased bonding interaction, while the $1 \delta \mathrm{MO}$ experiences little change energetically. The triplet is then formed by placing a single electron in the $1 \delta$ and $4 \sigma$ MOs. The bent triplet is favored over the bent singlet due to favorable exchange between electrons in these energetically close orbitals.

Adding more electrons causes $\left[\mathrm{Co}-\mathrm{O}_{2}\right]^{2+},\left[\mathrm{Ni}-\mathrm{O}_{2}\right]^{2+}$, $\left[\mathrm{Cu}-\mathrm{O}_{2}\right]^{2+}$, and $\left[\mathrm{Zn}-\mathrm{O}_{2}\right]^{2+}$ to become increasingly more bent. For $\left[\mathrm{Co}-\mathrm{O}_{2}\right]^{2+}$ and $\left[\mathrm{Ni}-\mathrm{O}_{2}\right]^{2+}$, the $1 \delta$ and $4 \sigma \mathrm{MOs}$ 


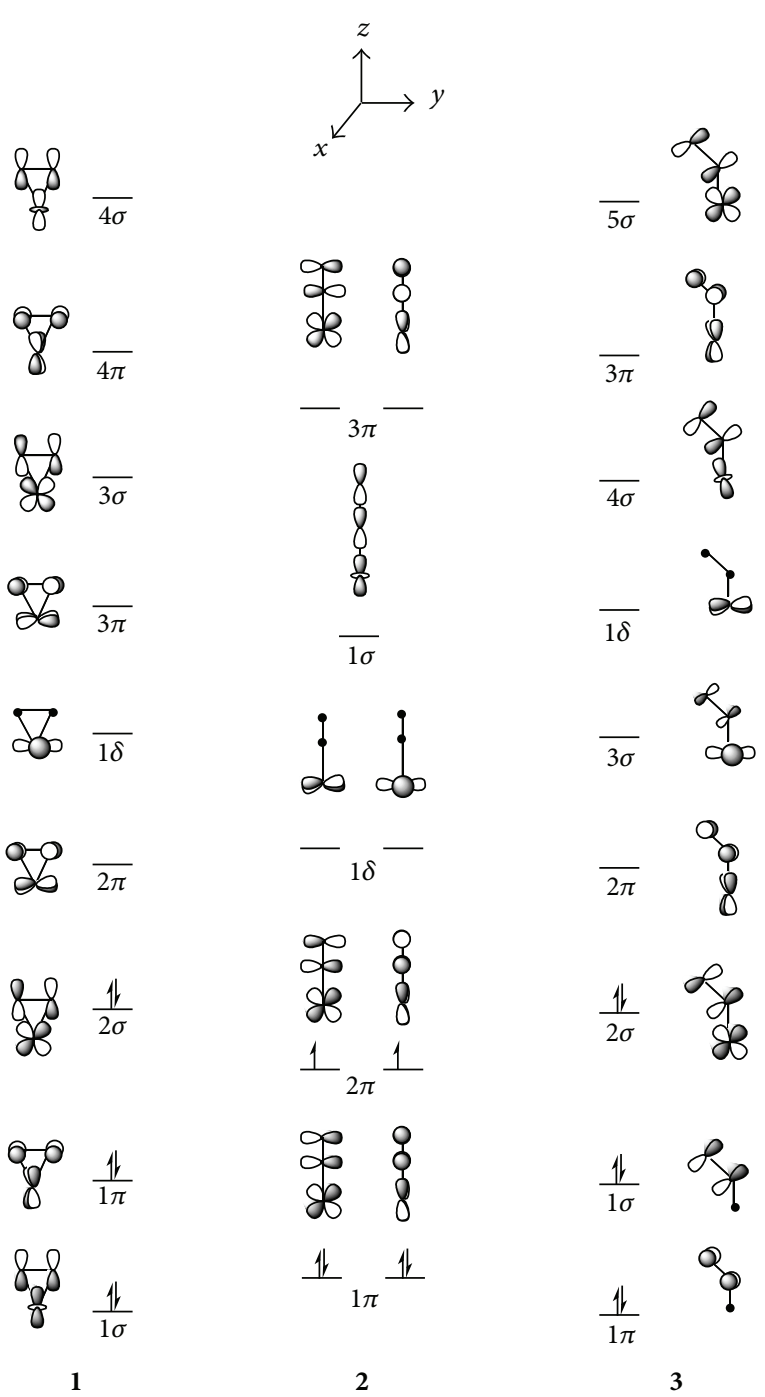

SCHEME 3

\section{Conclusions}

In the current study, we present the lowest energy geometrical conformations and spin states of first row [TM$\left.\mathrm{O}_{2}\right]^{2+}$ molecules. $\left[\mathrm{Sc}-\mathrm{O}_{2}\right]^{2+}$ is trigonal, while $\left[\mathrm{Ti}-\mathrm{O}_{2}\right]^{2+}$ $\left[\mathrm{Mn}-\mathrm{O}_{2}\right]^{2+}$ are linear and $\left[\mathrm{Fe}-\mathrm{O}_{2}\right]^{2+}-\left[\mathrm{Zn}-\mathrm{O}_{2}\right]^{2+}$ are bent. The $\mathrm{O}-\mathrm{O}$ bond length decreases as the TM goes from $\mathrm{Sc}$ to $\mathrm{Zn}$, whereas the $\mathrm{TM}-\mathrm{O}_{2}$ bond length fluctuates. For [Mn$\left.\mathrm{O}_{2}\right]^{2+},\left[\mathrm{Fe}-\mathrm{O}_{2}\right]^{2+},\left[\mathrm{Cu}-\mathrm{O}_{2}\right]^{2+}$, and $\left[\mathrm{Zn}-\mathrm{O}_{2}\right]^{2+}$ molecules, high spin states are lowest in energy indicating degenerate or near-degenerate orbitals.

Although it is clear that there is some level of electron transfer from the $\mathrm{O}_{2}$ to the TM as well as some degree of TM to $\mathrm{O}_{2}$ back donation, a more detailed analysis is required in order to fully understand the bonding in these unique molecules and how that extends to larger molecules of biological and industrial importance. Furthermore, we have shown that while the current results can be used as a starting point for studies of TM- $\mathrm{O}_{2}$ containing molecules with $\sigma$ donor and $\pi$ acceptor ligands, caution must be exercised as both high- and low-spin ground states are possible.

\section{Acknowledgments}

This work was supported by the Research Corporation Cottrell College Science Award CC6519. The authors thank the School of Science and the office of the Academic Vice President of Academic Affairs at Marist College for continued support of research.

\section{References}

[1] A. L. Feig and S. J. Lippard, "Reactions of non-heme iron(II) centers with dioxygen in biology and chemistry," Chemical Reviews, vol. 94, no. 3, pp. 759-805, 1994.

[2] N. Kitajima and Y. Moro-oka, "Copper-dioxygen complexes. Inorganic and bioinorganic perspectives," Chemical Reviews, vol. 94, no. 3, pp. 737-757, 1994.

[3] J. Muzart, "Chromium-catalyzed oxidations in organic synthesis," Journal of Chemical Reviews, vol. 92, no. 1, pp. 113-140, 1992.

[4] D. Dolphin, T. G. Traylor, and L. Y. Xie, "Polyhaloporphyrins: unusual ligands for metals and metal-catalyzed oxidations," Accounts of Chemical Research, vol. 30, no. 6, pp. 251-259, 1997.

[5] D. H. Busch and N. W. Alcock, "Iron and cobalt "lacunar" complexes as dioxygen carriers," Chemical Reviews, vol. 94, no. 3, pp. 585-623, 1994.

[6] G. H. Loew and D. Harris, "Role of the heme active site and protein environment in structure, spectra, and function of the cytochrome P450s," Chemical Reviews, vol. 100, no. 2, pp. 407420, 2000.

[7] A. Butler, M. J. Clague, and G. E. Meister, "Vanadium peroxide complexes," Chemical Reviews, vol. 94, no. 3, pp. 625-638, 1994.

[8] K. Shikama, "The molecular mechanism of autoxidation for myoglobin and hemoglobin: A venerable puzzle," Chemical Reviews, vol. 98, no. 4, pp. 1357-1374, 1998.

[9] M. H. Dickman and M. T. Pope, "Peroxo and superoxo complexes of chromium, molybdenum, and tungsten," Chemical Reviews, vol. 94, no. 3, pp. 569-584, 1994. 
[10] J. P. Collman and L. Fu, "Synthetic models for hemoglobin and myoglobin," Accounts of Chemical Research, vol. 32, no. 6, pp. 455-463, 1992.

[11] E. L. Uzunova, H. Mikosh, and G. St. Nikolov, "Electronic structure of oxide, peroxide, and superoxide clusters of the $3 \mathrm{~d}$ elements: a comparative density functional study," Journal of Chemical Physics, vol. 128, Article ID 094307, 2008.

[12] Y. Gong, M. Zhou, and L. Andrews, "Spectroscopic and theoretical studies of transition metal oxides and dioxygen complexes," Chemical Reviews, vol. 109, no. 12, pp. 6765-6808, 2009.

[13] I. Bytheway and M. B. Hall, "Theoretical calculations of metaldioxygen complexes," Chemical Reviews, vol. 94, no. 3, pp. 639658, 1994.

[14] B. D. Olafson and W. A. Goddard III, "Molecular description of dioxygen bonding in hemoglobin," Proceedings of the National Academy of Sciences of the United States of America, vol. 74, no. 4, pp. 1315-1319, 1977.

[15] W. A. Goddard and B. D. Olafson, "Ozone model for bonding of an $\mathrm{O}_{2}$ to heme in oxyhemoglobin," Proceedings of the National Academy of Sciences of the United States of America, vol. 72, no. 6, pp. 2335-2339, 1975.

[16] H. Chen, M. Ikeda-Saito, and S. Shaik, "Nature of the Fe- $\mathrm{O}_{2}$ bonding in oxy-myoglobin: effect of the protein," Journal of the American Chemical Society, vol. 130, no. 44, pp. 14778-14790, 2008.

[17] A. D. Becke, "Density-functional thermochemistry. III. The role of exact exchange," Journal of Chemical Physics, vol. 98, pp. 5648-5653, 1993.

[18] B. Miehlich, A. S. Savin, and H. Preuss, "Results obtained with the correlation energy density functionals of becke and Lee, Yang and Parr," Chemical Physics Letters, vol. 157, no. 3, pp. 200206, 1989.

[19] C. Lee, W. Yang, and R. G. Parr, "Development of the ColleSalvetti correlation energy formula into a functional of the electron density," Physical Review B, vol. 37, pp. 785-789, 1988.

[20] P. J. Hay and W. R. Wadt, "Ab initio effective core potentials for molecular calculations. Potentials for the transition metal atoms Sc to Hg," Journal of Chemical Physics, vol. 82, p. 270, 1985.

[21] W. R. Wadt and P. J. Hay, "Ab initio effective core potentials for molecular calculations. Potentials for main group elements $\mathrm{Na}$ to Bi," The Journal of Chemical Physics, vol. 82, no. 1, pp. 284298, 1985.

[22] P. J. Hay and W. R. Wadt, "Ab initio effective core potentials for molecular calculations. Potentials for K to Au including the outermost core orbitals," Journal of Chemical Physics, vol. 82, pp. 299-311, 1985.

[23] C. E. Check, T. O. Faust, T. M. Bailey, B. J. Wright, T. M. Gilberrt, and L. S. Snderlin, "Addition of polarization and diffuse functions to the LANL2DZ basis set for P-block elements," The Journal of Physical Chemistry A, vol. 105, no. 34, pp. 8111-8116, 2001.

[24] D. Hegarty and M. A. Robb, "Application of unitary group methods to configuration interaction calculations," Molecular Physics, vol. 38, no. 6, pp. 1795-1812, 1979.

[25] R. H. E. Eade and M. A. Robb, "Direct minimization in mc scf theory. The quasi-newton method," Chemical Physics Letters, vol. 83, no. 2, pp. 362-368, 1981.

[26] H. B. Schlegel and M. A. Robb, "MC SCF gradient optimization of the $\mathrm{H}_{2} \mathrm{CO} \rightarrow \mathrm{H}_{2}+\mathrm{CO}$ transition structure," Chemical Physics Letters, vol. 93, no. 1, pp. 43-46, 1982.
[27] F. Bernardi, A. Bottini, J. J. W. McDougall, M. A. Robb, and H. B. Schlegel, "MCSCF gradient calculation of transition structures in organic reactions," Faraday Symposia of the Chemical Society, vol. 19, pp. 137-147, 1984.

[28] N. Yamamoto, T. Vreven, M. A. Robb, M. J. Frisch, and H. B. Schlegel, "A direct derivative MC-SCF procedure," Chemical Physics Letters, vol. 250, no. 3-4, pp. 373-378, 1996.

[29] M. J. Frisch, I. N. Ragazos, M. A. Robb, and H. B. Schlegel, "An evaluation of three direct MC-SCF procedures," Chemical Physics Letters, vol. 189, no. 6, pp. 524-528, 1992.

[30] Gaussian 03, Revision D. 02, M. J. Frisch et al., Wallingford, CT, 2003.

[31] NIST Chemistry WebBook, 2013, http://webbook.nist.gov/ chemistry/. 

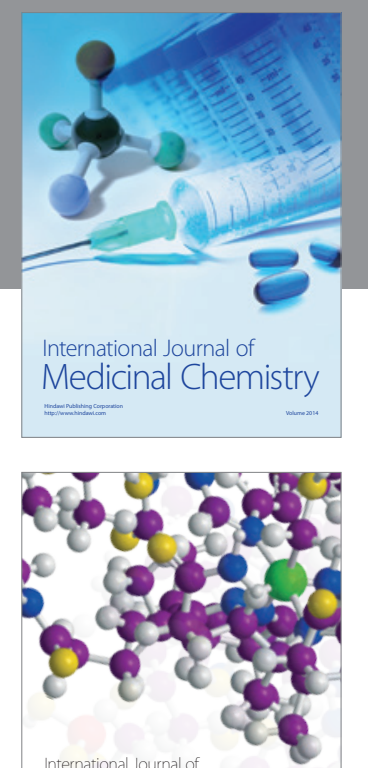

\section{Carbohydrate} Chemistry

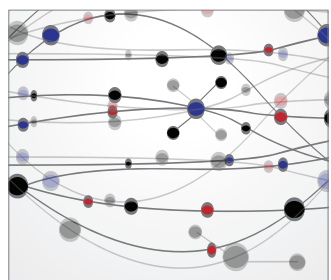

The Scientific World Journal
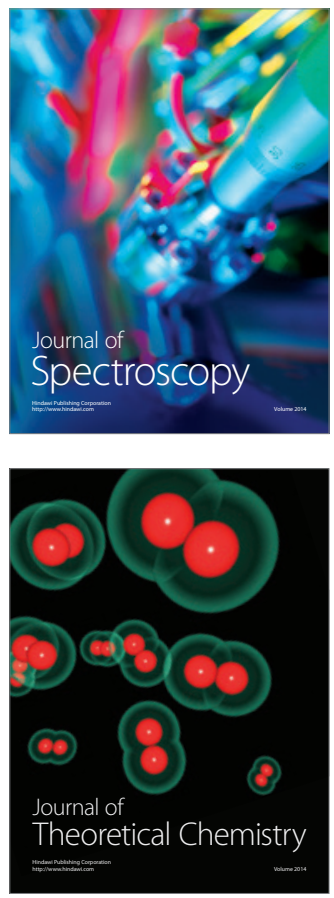
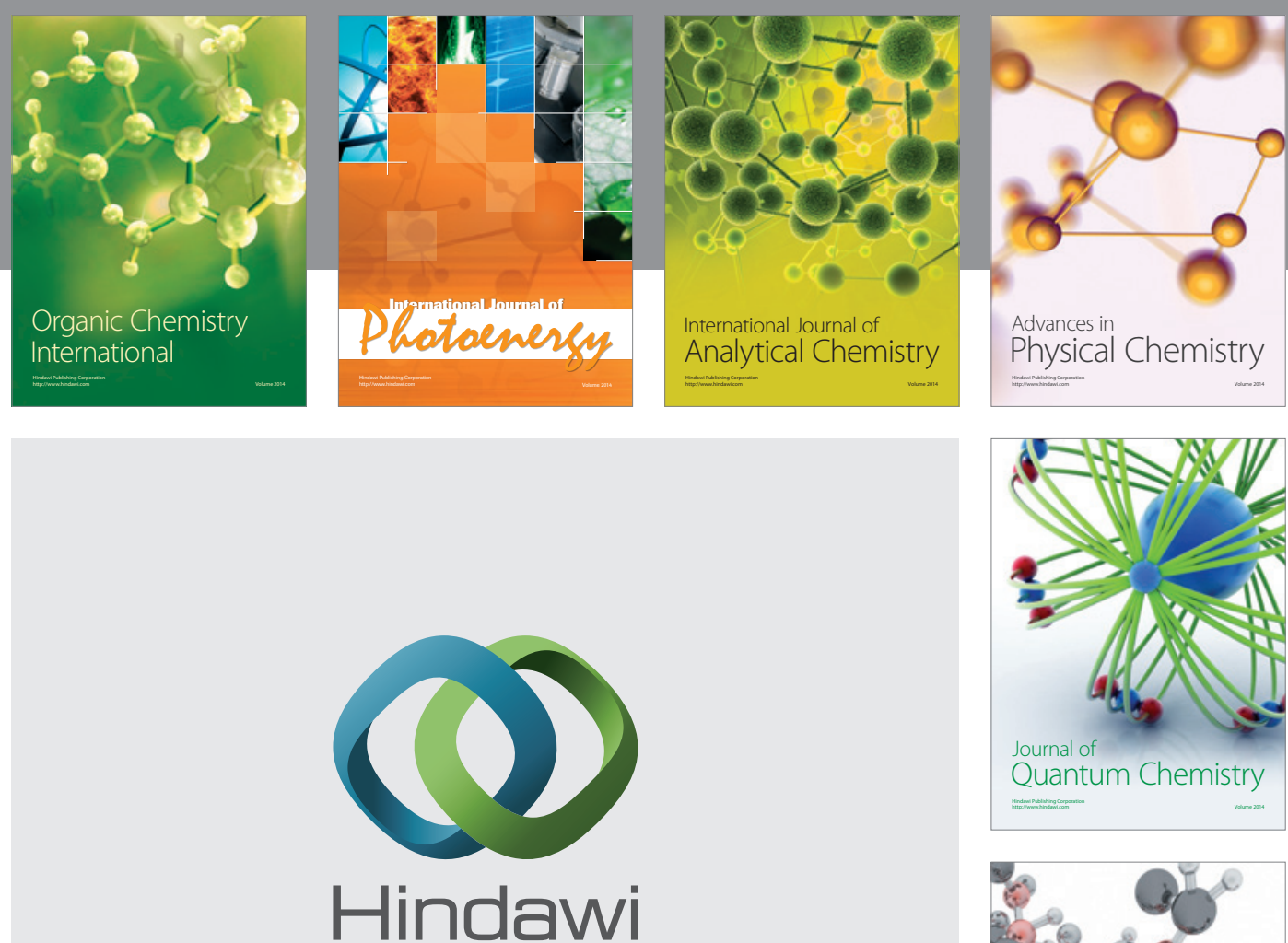

Submit your manuscripts at

http://www.hindawi.com

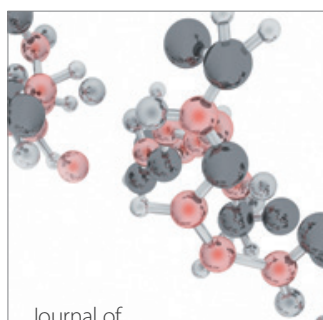

Analytical Methods

in Chemistry

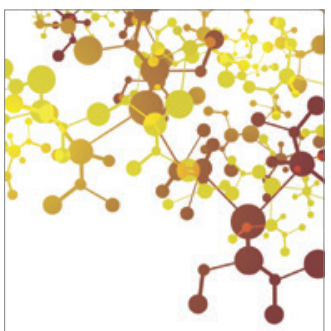

Journal of

Applied Chemistry

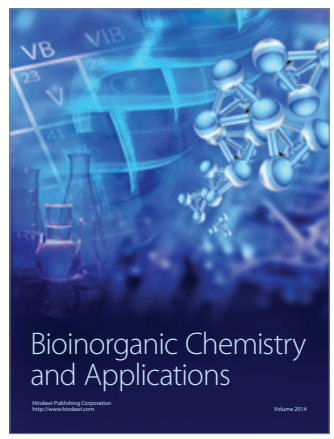

Inorganic Chemistry
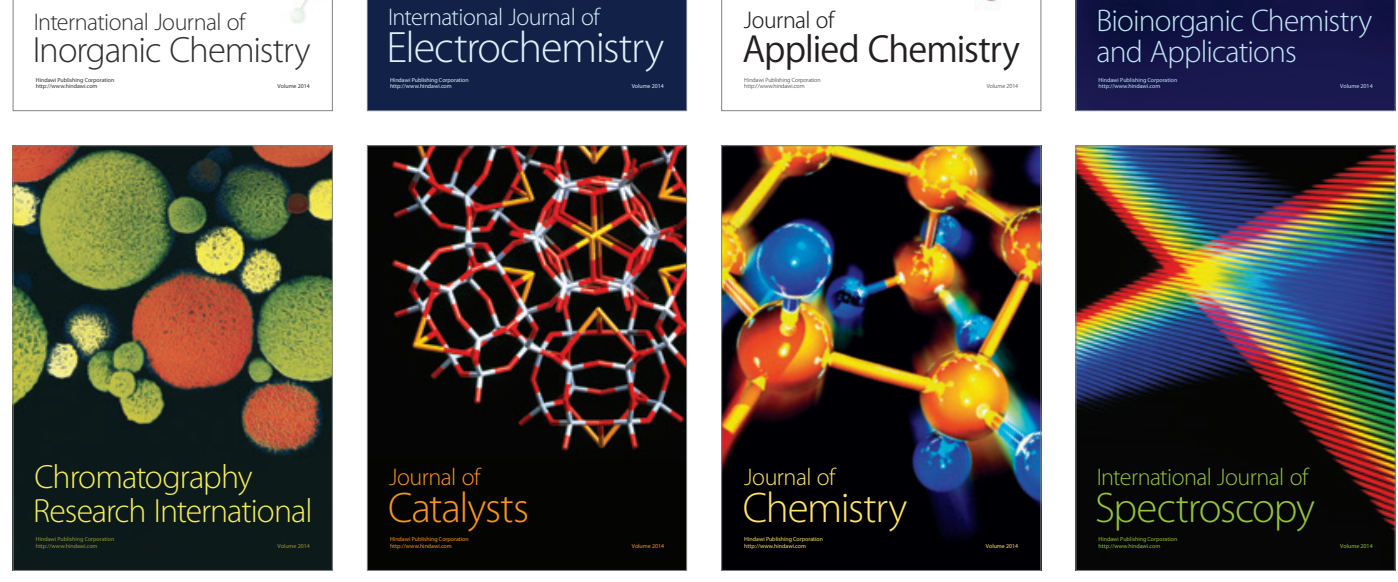